\title{
Enhancing the Organizational Citizenship Behavior: Comparative Research and Ex- Post-Facto Method on Generation X and Generation Y
}

\author{
Indra Wahyu ${ }^{1}$, Anoesyirwan Moeins ${ }^{2}$, Widodo Sunaryo ${ }^{3}$ \\ ${ }^{1,2,3}$ Pakuan University, Indonesia
}

\begin{abstract}
The purpose of this study is to find an effort to increase organizational citizenship behavior of Generation X and Generation Y employees through the identification of the influence of servant leadership and work motivation. This research was conducted on Generation X employees are Governmental Officers aged 44 55 years and Generation Y employees are Governmental Officers aged 23 - 43 years at Bogor Regency. The research sample was 180 persons of Generation $X$ and 86 persons of Generation Y from 3 agencies and 11 offices at Bogor Regency. This research uses a comparative approach and ex-post-facto and is completed by a qualitative approach through the Delphi technique. The findings revealed that variable and each dimension of $O C B$ Generation $Y$ is higher than $O C B$ than Generation $X$, servant leadership has a significant and positive effect on $O C B$ Generation $X$ and Generation $Y$, work motivation has a significant and positive effect on $O C B$ Generation $X$ and Generation $Y$, servant leadership and work motivation has a significant and positive effect on $O C B$ Generation $X$ and Generation $Y$, contribution servant leadership and work motivation of Generation $Y$ is higher than Generation $X$. The results of quantitative and qualitative research conclude that the improvement of the organizational citizenship behavior $(O C B)$ of Generation $X$ and Generation $Y$ employees can be done through strengthening servant leadership and work motivation.
\end{abstract}

Keywords: Generation X, generation Y, organizational citizenship behavior (OCB), servant leadership, work motivation.

\section{INTRODUCTION}

Agencies and Services in Bogor Regency are Government Organizations working in the public service sector. One way to improve the quality of public services is by increasing the Organizational Citizenship Behavior (OCB) of Generation X and Generation Y employees. The Research Gap from this study is based on data from the Central Statistics Agency (BPS) in 2018, that the HDI value (Human Development Index) from Bogor Regency, which is 69.13, which is still low compared to the average HDI score of Regency / City in West Java of 71.30 (15th place out of 27) and the District / City HDI value in the Indonesian territory of Indonesia is 71.39 (ranked 205th out of a total of 514) and based on the 2019 Bogor Regency Government Performance Report / LAKIP data, that of the 23 Performance Indicators, 14 indicators $(60.9 \%)$ have been achieved and 9 indicators (39.1\%) have not been achieved. Based on this, a preliminary survey has been conducted to see the quality of public services from OCB behavior of Generation $\mathrm{X}$ and Generation $\mathrm{Y}$ employees. The results of the preliminary survey found that $46 \%$ of Gen X employees and $31 \%$ of Gen Y employees have problems with voluntary actions, $53 \%$ of employees Gen X and $40 \%$ of Gen Y employees have problems with Compliance with Rules, $65 \%$ of Gen X Employees and 53\% of Gen Y Employees have problems with Tolerance Attitudes, $65 \%$ of Gen X Employees and 34\% of Gen Y Employees have problems with Work Ethics, $48 \%$ of Gen Y Employees X and 42\% of Gen Y employees have problems with Moral Obligations, $68 \%$ of Gen X employees and $60 \%$ of Gen Y employees have problems with Initiative Attitudes, and $61 \%$ of Gen X employees and $46 \%$ of Gen Y employees have problems with Personal Development. This study is to find efforts to improve OCB by identifying the influence and differences of Servant leadership and Work Motivation on OCB Generation X and Generation Y employees in Bogor Regency.

\section{LITERATURE REVIEW AND HYPOTHESIS DEVELOPMENT}

Luthans (2011) argues that OCB is the characteristics or traits, certain personalities contained in individuals, namely cooperative traits, likes to help and care for others and sincerity to work. According to Colquitt et al. (2014) OCB is the voluntary behavior of individuals who are not affected by the reward system for contributions 
to the organization, while Gibson et al. (1991) OCB is the behavior of individuals to do work outside their assigned work effectively and efficiently without considering rewards or bonus, but it supports organizational value. Podsakoff et al. (2000) stated that OCB can affect organizational effectiveness because it helps increase coworker productivity, managerial productivity, efficient organizational resources, the stability of organizational performance and adapts to changes in its business environment. From the opinion of Colquitt et al. (2014), Gibson et al. (1991), Luthans (2011), and Podsakoff et al. (2000) can summarize that there are several dimensions of OCB, namely (1) Altruism is the behavior of helping colleagues in completing work in unusual situations, without coercion from other parties, (2) Conscientiousness is the behavior of carrying out tasks and responsibilities that exceed the expected minimum standards, (3) Sportsmanship is behavior that describes sportsmanship and tolerance towards the organization, shown by looking at positive aspects of the organization compared to negative aspects, (4) Courtesy is behavior that alleviates problems with work faced by colleagues, (5) Civic Virtue is behavior that describes support for administrative functions, (6) Individual Initiative is behavior developing a way of working that is better than today and the implementation of tasks that are more than the set standards and (7) Self Development is the behavior of increasing personal competence and following the latest developments.

Robbins \& Judge (2017) define servant leadership as a leadership style that is characterized by going beyond the leader's interests and will focus on opportunities to help followers grow and develop. According to Spears (2010), servant leadership is a leader who prioritizes service, starting with the natural feeling of someone who wants to serve and to put service first. Meanwhile, Barbuto Jr et al. (2014) servant leadership is leadership that has a natural desire to serve others. From the opinion of Barbuto Jr et al. (2014), Robbins \& Judge (2017), and Spears (2010) can summarize that there are several dimensions of serving leadership, namely: (1) Listening is a leader who listens attentively to others, without coercion from other parties, (2) Empathy is a leader who tries to understand colleagues and can empathize with others, (3) Healing is a leader who can create emotional healing and relationships himself, or relationships with others, (4) Awareness is a leader who is aware of understanding issues involving ethics, power, and values, (5 ) Persuasion is a leader who serves trying to convince others rather than forcing obedience, (6) Conceptualization is a leader who can see the problem from a conceptualization point of view and (7) Stewardship is a leader who emphasizes openness and persuasion to build trust from others. Research by Al-Amri et al. (2016) concluded that servant leadership has a significant and positive influence on employee OCB with F count $=13.165>\mathrm{F}$ table and Sig. $<0.05$.

Robbins \& Judge (2019) define motivation as a process that explains the strength, direction, and persistence of a person to achieve goals. Luthans (2011) motivation is a process that begins with physiological or psychological deficiencies that drive behaviors or drives aimed at goals and incentives. Meanwhile, Griffin \& Moorhead (2014) stated that motivation is a series of forces that cause people to behave in certain ways. From the opinion of Griffin \& Moorhead (2014), Luthans (2011), and Robbins \& Judge (2019) can be summarized that there are 2 (two) factors of motivation, namely the intrinsic factor which consists of the drive for self-achievement and reward for work performance, and extrinsic factors consisting of salary and other benefits, hierarchical level, promotion, work environment and coworkers. Research by Shaaban (2018) concludes that intrinsic work motivation has a significant and positive effect on employee OCB of t count $=6.175>\mathrm{t}$ table and Sig. $<0.05$, and extrinsic work motivation has a significant and positive effect on employee OCB of $t$ count $=9.620>t$ table and Sig. $<0.05$.

Tapscott \& Barry (2009) defines Generation X known as the baby bust as the generation born in 1965-1976. Generation $\mathrm{X}$ is one of the best-educated groups in history. Generation $\mathrm{X}$ is aggressive communicators who are very media-centric. Generation $\mathrm{X}$ sees radio, TV, movies, and the Internet, available for everyone to use to package information and submit it their way, whereas Generation Y known as the net generation or millennial is the generation born in 1977-1997. Influencing Generation Y is the rise of computers, the internet, and other digital technologies. Bencsik \& Machova (2016) divide Generation X's behavior into several factors, namely self-centered and medium-term views, work goals can adapt to various environments, seek a safe position, and have the desire to get a fast promotion, utilize IT technology with confidence, and have values such as hard work, openness, respect for differences, curiosity, and practicality, while Generation Y's behavior is divided into several factors, namely its view is centered on egoism and the short term, relationships are virtual networks and networks, work goals are trying to get a position as a leader and promotion, utilizing IT technology, and have values such as flexibility, mobility, broad but shallow knowledge, success orientation, creativity, and freedom of information as priorities. 
Research by Mahnaz et al. (2013) concluded that there is a significant difference between OCB Generation X and Generation $\mathrm{Y}(\alpha \leq 0.030, \mathrm{p}<0.05)$, research by Kraus (2017) concludes that there are significant differences in servant leadership for Generation $\mathrm{X}$ and $\mathrm{Y}$ with $\mathrm{F}$ count $=16.541>\mathrm{F}$ table and $\mathrm{p}<0.01$, and research by Tan \& Wan Yusoff (2012) concluded that there is a significant difference in intrinsic work motivation between Generation $\mathrm{X}$ and $\mathrm{Y}$ of $\mathrm{t}$-count $=25.277$ and Sig. $<0.05$, and there is a significant difference in extrinsic work motivation between Generation $\mathrm{X}$ and $\mathrm{Y}$ at $\mathrm{t}$ count $=25.818$ and Sig. <0.05. Based on this explanation, the following research hypothesis can be formulated:

H1 There are differences in employee OCBs between Generation X and Generation $Y$

H2 There are differences between Generation X and Generation Y in each dimension of Employee OCB

H3 There is a positive influence of Servant leadership on Employee OCB in Generation X

H4 There is a positive influence on work motivation on employee OCB in Generation X

H5 There is a positive influence of servant leadership and work motivation together on Employee OCB in Generation X

H6 There is a positive influence of servant leadership on Employee OCB in Generation $Y$

H7 There is a positive influence on work motivation on employee OCB in Generation $Y$

H8 There is a positive influence of servant leadership and work motivation together on Employee OCB in Generation $Y$

H9 There are differences in the influence of servant leadership on employee OCB in Generation $X$ and Generation $Y$

H10 There are differences in the influence of work motivation on employee OCB in Generation $X$ and Generation $Y$

\section{RESEARCH METHOD}

\section{Population and Research Sample}

The research was conducted from August 2019 to July 2020 in Bogor Regency, West Java Province, Indonesia. The study population was 328 Generation $\mathrm{X}$ and 110 Generation Y from permanent state civil servants from 3 Agencies and 11 Services in Bogor Regency. The research sample of 180 Generation X employees and 86 Generation Y employees were taken from the population calculated by the Slovin formula with an error margin of $5 \%$.

\section{Research Framework}

Based on the hypothesis, the formulation of a framework of thought can be explained below: 


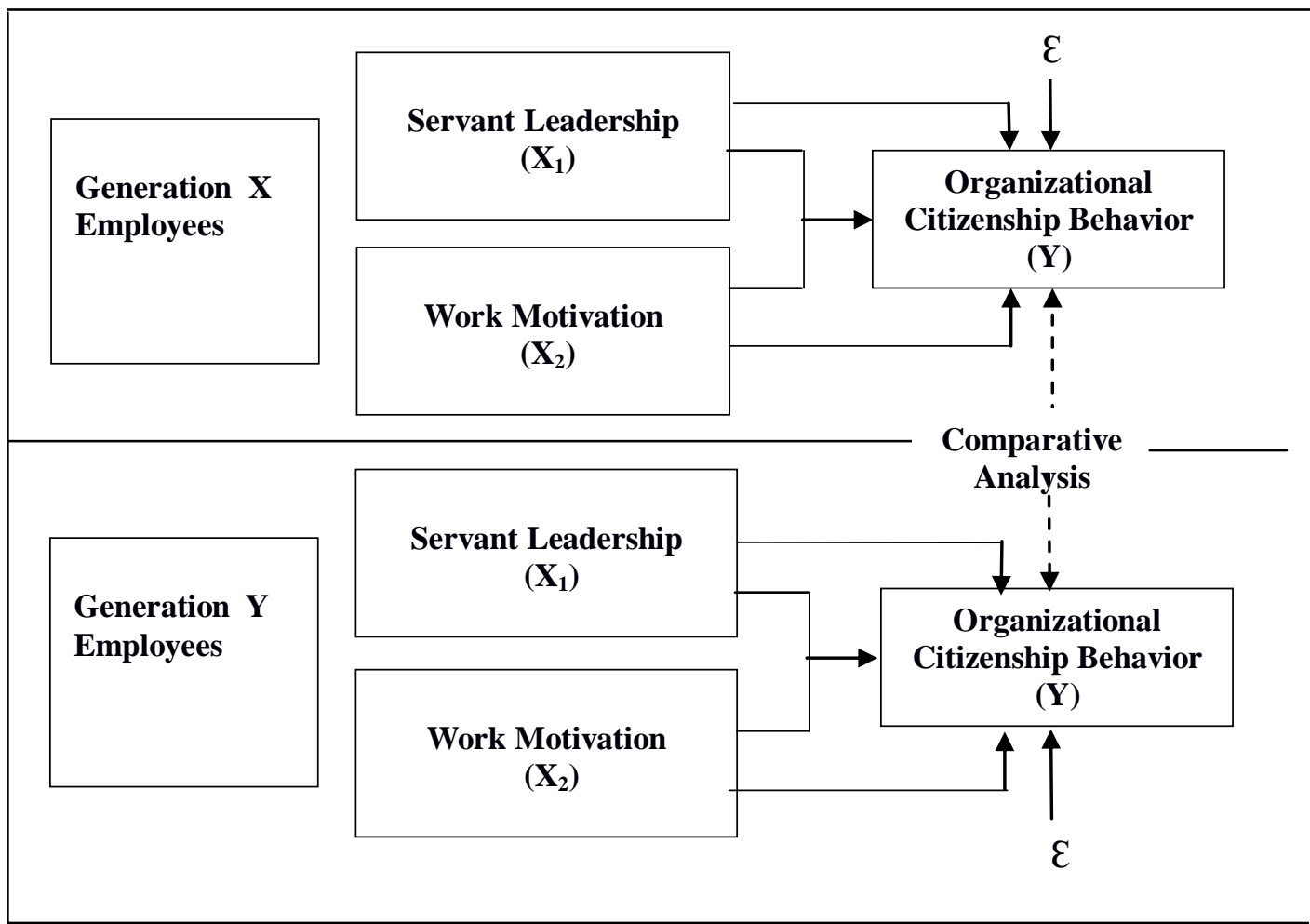

Figure 1. Research Framework

\section{Data Collection and Analysis}

The research was conducted quantitatively and qualitatively using a questionnaire. The quantitative stage is carried out as follows: 1) Validity Test with the Pearson Product Moment Correlation formula and Reliability Test with Alpha Cronbach formula, 2) Liliefors Normality Test, 3) Bartlett Homogeneity Test, 4) Linearity and Significance Test of Regression Equations, and 4) Hypothesis Test (Sugiyono, 2013). For the qualitative stage, the Delphi technique was carried out in the form of group conclusions and triangulation, then the qualitative results were compared with the quantitative results.

\section{RESULTS AND DISCUSSION}

Validity and Reliability Test

Table 1. Reliability Coefficient of the Questionnaire

\begin{tabular}{clcccc}
\hline No. & Questionnaire Measurement & Item & Rated by & Validity & Reliability \\
\hline 1 & $\begin{array}{l}\text { Organizational Citizenship } \\
\text { Behavior }\end{array}$ & 34 & $\begin{array}{l}\text { Gen X and Gen Y } \\
\text { employees }\end{array}$ & r $>0.254$ & 0.907 \\
2 & Servant Leadership & 34 & $\begin{array}{l}\text { Gen X and Gen Y } \\
\text { employees }\end{array}$ & $\mathrm{r}>0.254$ & 0.904 \\
\hline
\end{tabular}

Obtained 34 items from 42 questionnaire items that are valid and reliable. 


\section{Normality Test}

Table 2. Results of Generation X Employee Normality

\begin{tabular}{llccc}
\hline No. & Description & OCB & Servant Leadership & $\begin{array}{c}\text { Motivation } \\
\text { Work }\end{array}$ \\
\hline 1 & Empirical Data & 0.0606 & 0.0642 & 0.0571 \\
2 & Liliefors Standard & 0.0660 & 0.0660 & 0.0660 \\
3 & Result & Empirical < Standard & Empirical < Standard & Empirical < Standard \\
\hline
\end{tabular}

Table 3. Results of Generation Y Employee Normality

\begin{tabular}{clccc}
\hline No. & Description & OCB & Servant Leadership & $\begin{array}{c}\text { Motivation } \\
\text { Work }\end{array}$ \\
\hline 1 & Empirical Data & 0.0947 & 0.0914 & 0.0643 \\
2 & Liliefors Standard & 0.0956 & 0.0956 & 0.0956 \\
3 & Result & Empirical <Standard & Empirical <Standard & Empirical <Standard \\
\hline
\end{tabular}

Conclusion: Data from the OCB questionnaire, Servant leadership, and employee work motivation Generation X and Generation Y come from populations that are normally distributed.

\section{Bartlett Homogeneity Test}

Table 4. Results of Generation X Employee Homogeneity

\begin{tabular}{llcc}
\hline No. & Description & $\begin{array}{c}\text { OCB above } \\
\text { Servant Leadership }\end{array}$ & $\begin{array}{c}\text { OCB above } \\
\text { Work motivation }\end{array}$ \\
\hline 1 & Empirical Data & 0.103 & 0.339 \\
2 & Sig Value. & 0.05 & 0.05 \\
3 & Result & Empirical $>$ Sig. & Empirical> Sig. \\
\hline
\end{tabular}

Table 5. Results of Generation Y Employee Homogeneity

\begin{tabular}{llcc}
\hline No. & Description & $\begin{array}{c}\text { OCB above } \\
\text { Servant Leadership }\end{array}$ & $\begin{array}{c}\text { OCB above } \\
\text { Work motivation }\end{array}$ \\
\hline 1 & Empirical Data & 0.847 & 0.701 \\
2 & Sig Value. & 0.05 & 0.05 \\
3 & Result & Empirical $>$ Sig. & Empirical $>$ Sig. \\
\hline
\end{tabular}

Conclusion: Data from the OCB questionnaire, servant leadership, and employee work motivation Generation X and Generation Y come from a population that is homogeneously distributed. 


\section{Linearity Test and Significance of Regression Equations}

Table 6. Results of Linearity Test and Significance of Regression Equations Generation X employees

\begin{tabular}{clcc}
\hline No. & Description & Servant Leadership with OCB & $\begin{array}{c}\text { Work Motivation } \\
\text { with OCB }\end{array}$ \\
\hline 1 & F count & 1,207 & 1,238 \\
2 & F table & 3.05 & 3.05 \\
3 & Empirical Data & 0.210 & 0.192 \\
4 & Sig value. & 0.05 & 0.05 \\
5 & Result & F count $<$ F table & F count <F table \\
& & Empirical Data $>$ Sig. & Empirical Data $>$ Sig. \\
\hline
\end{tabular}

Table 7. Linearity Test Results and Significance of Regression Equations Generation Y employees

\begin{tabular}{clcc}
\hline No. & Description & Servant Leadership with OCB & $\begin{array}{c}\text { Work Motivation } \\
\text { with OCB }\end{array}$ \\
\hline 1 & F count & 0.690 & 1,860 \\
2 & F table & 3.11 & 3.11 \\
3 & Empirical Data & 0.876 & 0.053 \\
4 & Sig value. & 0.05 & 0.05 \\
5 & Result & F count $<$ F table & F count $<$ F table \\
& & Empirical Data Sig. & Empirical Data $>$ Sig. \\
\hline
\end{tabular}

Conclusion: The relationship between servant leadership and OCB and the relationship of work motivation with OCB Generation X and Generation Y is linear and significant.

\section{Hypothesis Test Results Based on Quantitative Research Results}

Table 8. Hypothesis Test Results

\begin{tabular}{|c|c|c|}
\hline No. & Variables / Dimensions & Conclusion Test \\
\hline \multirow[t]{2}{*}{1} & OCB variables for & $\mathrm{p}<0.05$ \\
\hline & $\begin{array}{l}\text { Generation } \mathrm{X} \text { and Generation } \\
\text { Y employees with the Mann } \\
\text { Whitney test }\end{array}$ & $\begin{array}{l}\text { Ho is rejected, } \mathrm{H} 1 \text { is accepted. There is a significant difference } \\
\text { between OCB Generation } \mathrm{X} \text { and OCB Generation Y, where } \\
\text { OCB Generation Y is higher than Generation X. }\end{array}$ \\
\hline \multirow[t]{4}{*}{2} & Dimensions of the OCB & $\mathrm{p}<0.05$ \\
\hline & Variables Generation X and & Ho is rejected, $\mathrm{H} 1$ is accepted. \\
\hline & Generation Y employees with & There are differences between OCB Generation $\mathrm{X}$ and OCB \\
\hline & the Mann Whitney Test & $\begin{array}{l}\text { Generation Y, where each dimension of Generation Y OCB is } \\
\text { higher than Generation } \mathrm{X}\end{array}$ \\
\hline \multirow[t]{2}{*}{3} & $\begin{array}{l}\text { Servant leadership variables } \\
\text { against OCB Generation X } \\
\text { employees with t test }\end{array}$ & $\begin{array}{l}\mathrm{t} \text { count }(5,688)>\mathrm{t} \text { table, Sig. }<0.05 \text {, with the regression equation: } \\
\mathrm{Y}=88.642+0.345 \mathrm{X} 1 \\
\text { Ho is rejected, } \mathrm{H} 1 \text { is accepted. }\end{array}$ \\
\hline & & $\begin{array}{l}\text { There is a significant and positive influence of servant } \\
\text { leadership on the OCB of Generation X employees. }\end{array}$ \\
\hline 4 & $\begin{array}{l}\text { Work Motivation Variables } \\
\text { on OCB Generation X } \\
\text { employees with t test }\end{array}$ & $\begin{array}{l}\mathrm{t} \text { count }(9,111)>\mathrm{t} \text { table, Sig. }<0.05 \text {, with the regression equation: } \\
\mathrm{Y}=47.921+0.640 \mathrm{X} 2 \\
\text { Ho is rejected, } \mathrm{H} 1 \text { is accepted. }\end{array}$ \\
\hline
\end{tabular}




\begin{tabular}{|c|c|c|}
\hline & & $\begin{array}{l}\text { There is a significant and positive influence on work motivation } \\
\text { on OCB Generation X employees }\end{array}$ \\
\hline 5 & $\begin{array}{l}\text { Servant Leadership Variables } \\
\text { and Work Motivation } \\
\text { together on OCB Generation } \\
\text { X employees with the F Test }\end{array}$ & $\begin{array}{l}\text { F count }(83,011)>F \text { table, Sig. }<0.05 \text {, with the regression } \\
\text { equation: } \mathrm{Y}=42.265+0.126 \mathrm{X} 1+0.558 \mathrm{X} 2 \\
\text { Ho is rejected, } \mathrm{H} 1 \text { is accepted. } \\
\text { There is a significant and positive influence of servant } \\
\text { leadership and work motivation together on OCB of Generation } \\
\mathrm{X} \text { employees }\end{array}$ \\
\hline 6 & $\begin{array}{l}\text { Servant Leadership Variables } \\
\text { against OCB Generation Y } \\
\text { employees with t-test }\end{array}$ & $\begin{array}{l}t \text { count }(4,394)>t \text { table, Sig. }<0.05 \text {, with the regression equation: } \\
\mathrm{Y}=82.785+0.419 \mathrm{X} 1 \\
\text { Ho is rejected, } \mathrm{H} 1 \text { is accepted. } \\
\text { There is a significant and positive influence of servant } \\
\text { leadership on the OCB of Generation Y employees }\end{array}$ \\
\hline 7 & $\begin{array}{l}\text { Work Motivation Variable on } \\
\text { Employee Generation Y OCB } \\
\text { with t test }\end{array}$ & $\begin{array}{l}\mathrm{t} \text { count }(8,862)>\mathrm{t} \text { table, Sig. }<0.05 \text {, with the regression equation: } \\
\mathrm{Y}=48.961+0.662 \mathrm{X} 2 \\
\text { Ho is rejected, } \mathrm{H} 1 \text { is accepted. } \\
\text { There is a significant and positive influence of work motivation } \\
\text { on the OCB of Generation } \mathrm{Y} \text { employees }\end{array}$ \\
\hline 8 & $\begin{array}{l}\text { Servant Leadership Variables } \\
\text { and Work Motivation } \\
\text { together on OCB of } \\
\text { Generation Y employees with } \\
\text { the F Test }\end{array}$ & $\begin{array}{l}\text { F count }(38,875)>F \text { table, Sig. }<0.05 \text {, with the regression } \\
\text { equation: } Y=47.497+0.026 \mathrm{X} 1+0.646 \mathrm{X} 2 \\
\text { Ho is rejected, H1 is accepted. } \\
\text { There is a significant and positive influence of servant } \\
\text { leadership and work motivation together on OCB of Generation } \\
\text { Y employees }\end{array}$ \\
\hline 9 & $\begin{array}{l}\text { Servant Leadership Variables } \\
\text { towards Employee OCB in } \\
\text { Generation X and Generation } \\
\text { Y with Mann Whitney Test } \\
\text { and Coefficient of } \\
\text { Determination }\end{array}$ & $\begin{array}{l}\mathrm{p}<0.05, \mathrm{R} 2 \mathrm{Gen} \mathrm{Y}(18.7 \%)>\mathrm{R} 2 \mathrm{Gen} \mathrm{X}(15.4 \%) \\
\text { Ho is rejected, } \mathrm{H} 1 \text { is accepted. } \\
\text { There is a significant difference between the Servant leadership } \\
\text { of Generation } \mathrm{X} \text { and Generation } \mathrm{Y} \text { employees, and the } \\
\text { difference in the contribution of the influence of Servant } \\
\text { leadership on OCB for Generation } \mathrm{X} \text { and Generation } \mathrm{Y} \\
\text { employees, where the Servant leadership of Generation } \mathrm{Y} \\
\text { employees is higher than Generation X. }\end{array}$ \\
\hline 10 & $\begin{array}{l}\text { Work Motivation Variables } \\
\text { on Employee OCB in } \\
\text { Generation X and Generation } \\
\text { Y with Mann Whitney Test } \\
\text { and Coefficient of } \\
\text { Determination }\end{array}$ & $\begin{array}{l}\mathrm{p}<0.05, \mathrm{R} 2 \mathrm{Gen} \mathrm{Y}(48.3 \%)>\mathrm{R} 2 \mathrm{Gen} \mathrm{X}(31.8 \%) \\
\text { Ho is rejected, } \mathrm{H} 1 \text { is accepted. } \\
\text { There is a significant difference in the influence of Work } \\
\text { Motivation from Generation } \mathrm{X} \text { and Generation } \mathrm{Y} \text { employees, } \\
\text { and the difference in the contribution of the influence of Work } \\
\text { Motivation on OCB for Generation X and Generation Y } \\
\text { employees, where work motivation from Generation Y is higher } \\
\text { than Generation X. }\end{array}$ \\
\hline
\end{tabular}

The results of qualitative research in the form of conclusions on group answers and triangulation can be concluded as follows:

a. The results of qualitative research support quantitative research of the variables and each dimension of OCB Generation X and Generation Y.

b. The results of qualitative research support quantitative research on the positive influence of Servant leadership on OCB of Generation X and Generation Y employees.

c. The results of qualitative research support quantitative research on the positive influence of work motivation on OCB for Generation X and Generation Y employees. 


\section{CONCLUSIONS AND SUGGESTIONS}

Based on the results of research at the quantitative and qualitative stages it can be concluded that this study has found efforts to improve the organizational citizenship behavior (OCB) of Generation X and Generation $\mathrm{Y}$ employees through servant leadership and work motivation, based on the following identification:

1. There is a significant difference between OCB Generation $\mathrm{X}$ with OCB Generation Y, where OCB Generation $\mathrm{Y}$ is higher than Generation $\mathrm{X}$.

2. There are differences between OCB Generation X and OCB Generation Y, where each dimension of Generation Y OCB is higher than Generation X.

3. There is a significant and positive influence of Servant leadership on OCB of Generation X employees.

4. There is a significant and positive influence on work motivation on OCB Generation X employees.

5. There is a significant and positive influence of servant leadership and Work Motivation together on OCB Generation X employees.

6. There is a significant and positive influence of servant leadership on the OCB of Generation Y employees.

7. There is a significant and positive influence on work motivation on the OCB of Generation $\mathrm{Y}$ employees.

8. There is a significant and positive influence of servant leadership and work motivation together on OCB of Generation Y employees.

9. There is a significant difference between the servant leadership of Generation $\mathrm{X}$ and Generation $\mathrm{Y}$ employees, and the difference in the contribution of the influence of Servant leadership on OCB for Generation X and Generation Y employees, where the Servant leadership of Generation Y employees is higher than Generation X.

10. There is a significant difference in the influence of work motivation from Generation $\mathrm{X}$ and Generation $\mathrm{Y}$ employees, and the difference in the contribution of the influence of work motivation on OCB for Generation X and Generation Y employees, where work motivation from Generation Y is higher than Generation X.

Based on the above conclusions, we propose the following suggestions:

1. Suggestions to improve the indicators of Generation $\mathrm{X}$ research variables can be done to do training OCB and Work Motivation for all Generation X employees, and servant leadership training for superiors from Generation X employees.

2. Suggestions for maintaining the indicators of Generation $Y$ research variables can be done through training and dissemination of OCB knowledge and work motivation for all Generation Y employees, and training through training and dissemination of knowledge on servant leadership for the superiors of Generation Y employees.

\section{REFERENCES}

[1] Al-Amri, M. S., Al Hajji, M. I., \& Alawaji, A. S. (2016). The Relationship between Servant Leadership and Organizational Citizenship Behavior: An Empirical Study on Saudi Insurance Companies. International Journal of Business and Management, $11(11), 264$.

[2] Barbuto Jr, J. E., Gottfredson, R. K., \& Searle, T. P. (2014). An examination of emotional intelligence as an antecedent of servant leadership. Journal of Leadership \& Organizational Studies, 21(3), 315-323.

[3] Bencsik, A., \& Machova, R. (2016). Knowledge sharing problems from the viewpoint of intergeneration management. ICMLG20164th International Conference on Management, Leadership and Governance: ICMLG2016, 42.

[4] Colquitt, J., Lepine, J. A., \& Wesson, M. J. (2014). Organizational Behavior: Improving Performance and Commitment in the Workplace (4e). New York, NY, USA: McGraw-Hill.

[5] Gibson, J. L., Ivancevich, J. M., Donnelly, J. H., \& Konopaske, R. (1991). Organizations: Behavior, structure, processes. Irwin Homewood, IL.

[6] Griffin, R. W., \& Moorhead, G. (2014). Managing People In Organization. South-Western: USA.

[7] Kraus, M. (2017). Comparing Generation X and Generation Y on their preferred emotional leadership style. Journal of Applied Leadership and Management, 5, 62-75. 
[8] Luthans, F. (2011). Organizational behavior: An evidence-based approach. McGraw-Hill Irwin,.

[9] Mahnaz, M. A., Mehdi, M., \& Abbolghasem, P. (2013). The effect of demographic characteristics on organizational citizenship behavior in the selected teaching hospitals in Tehran. African Journal of Business Management, 7(34), 3324-3331.

[10] Podsakoff, P. M., MacKenzie, S. B., Paine, J. B., \& Bachrach, D. G. (2000). Organizational citizenship behaviors: A critical review of the theoretical and empirical literature and suggestions for future research. Journal of Management, 26(3), 513-563.

[11] Robbins, S. P., \& Judge, T. A. (2017). Organizational behavior, Edition 17, Global edition. Boston: Pearson.

[12] Robbins, S. P., \& Judge, T. A. (2019). Organizational behavior. pearson.

[13] Shaaban, S. (2018). The Impact of Motivation on Organisational Citizenship Behaviour (OCB): The Mediation Effect of Employees' Engagement. Journal of Human Resource Management, 6(2), 58-66.

[14] Spears, L. C. (2010). Character and servant leadership: Ten characteristics of effective, caring leaders. The Journal of Virtues \& Leadership, 1(1), 25-30.

[15] Sugiyono. (2013). Metode Penelitian Pendidikan Pendekatan Kuantitaif, Kualitatif, dan R\&D. In Metode Penelitian Pendidikan Pendekatan Kuantitaif, Kualitatif, dan R\&D. https://doi.org/10.1007/s13398-014-0173-7.2

[16] Tan, S. K., \& Wan Yusoff, W. F. (2012). Generation $x$ and $y$ and their work motivation.

[17] Tapscott, D., \& Barry, B. (2009). Grown up digital: How the net generation is changing your world (Vol. 200). McGraw-Hill New York 